Pavel D. Simashenkov. Ideological surpassing of Philosophy // Modern European Researches. - Salzburg, 2019. - №4

\author{
Pavel D. Simashenkov, \\ Candidate of Historical Sciences, Associate Professor, Public Administration Chair, \\ "IMI" University, Samara, Russia \\ pavel.simashenckov@yandex.ru
}

\title{
IDEOLOGICAL SURPASSING OF PHILOSOPHY
}

\begin{abstract}
The article is devoted to the study of ideological and philosophical components correlation in the worldview formation. According to the author, it is fundamentally important to take for understanding Russian history and culture not speculative, but ideological coordinates as the basis. Ideology as a professed philosophy is incomparably higher than any palliative abstraction. It is necessary not to lower culture to the level of the masses, but to elevate a person to the level of culture, impossible without a cult.
\end{abstract}

Key words: Russian philosophy, ideology, aesthetics, religion, extremism, social ethics, history, Russian culture.

Introduction

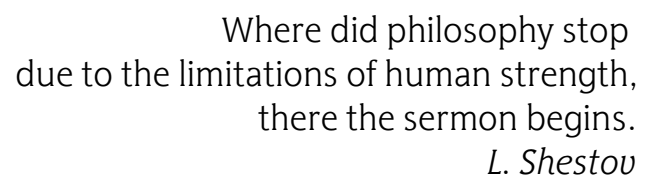

Consistency is the virtue of theory. Practice is usually chaotic and situational. It is possible to say from the height of the years lived: it is not shameful to follow any doctrine in youth, checking, consciously mastering it in practice - this is how the worldview becomes a conviction. The mature summation of empiricism is perhaps higher than philosophy, since it is gained through much suffering in one's own life. Everything starts with ideology, perceived in youth outwardly (a matter of honor). And everything ends with ideology that has become an internal conviction (a matter of conscience) and therefore convincing. In our opinion, the value of practice is more of a negative character: life experience protects from dogmatization and resonance, the so-called "religion of science." Theory plays a positive role in ideological synthesis; retrospective generalization is the best way to decipher omens and pave the way forward [1].

Philosophy is the efforts of the best minds to sew flaps of being with the white threads of their consciousness. External chaos is regulated by the inner peace. It is very possible that Christian philosophers embroider crosses on the canvas of being: according to G.Fedotov, no interpretation of the Russian national idea is possible without an internal introduction to Christianity [2]. A peculiar attitude to philosophy is also in full accordance with the national talent to master something without appropriating it. One can say that it is typical for Russians not to compare eternal questions in the interpretations of different thinkers so much as to study possible answers trying to fit philosophical accessories to the home-made garments of truth. "The most useless thing in the world is to be right," it is not just the bitter irony of a misunderstood person in this Tyutchev's aphorism, but also a warning: it's a sin to use the truth, reducing it to falsehood. The idea is emasculated, 
passing from imagination to consideration. Moreover, it stiffens, passing from the heart to the quotes.

\title{
Ideology and Faith
}

\begin{abstract}
The ideology we lived with has a permanent basis of Platonism: it doesn't see what it sees, and it doesn't mean what it means but lives only with memory. V. Bibikhin.
\end{abstract}

Any thought, being valuable and being extracted from the context, forms its own context: being realized in art, it gives rise to masterpieces; fertilizing politics - it becomes tendentious, makes the culture parody. There are times when culture and politics alternately play the roles of the due and the real, but they are more often correlated as reality and actuality. Both have retro and progressive components that can touch, be parallel, or contradict each other. It can hardly be argued that the course of things determines culture, and vice versa. It is necessary not to lower culture to the level of the masses, but to elevate a person to the level of culture (impossible without a cult). The essential and the vital are realized in consciousness, forming the continuum of which the person recognizes himself as a contemporary.

In fact, the era of geniuses will never come: they belong to Eternity; their cross is loneliness and doom to be for the time in the mortal world, not belonging this world. They are the bearers and conductors of timeless ideals, and therefore they live without becoming hardened by the spite of the day. Since ancient times, the Russian people preferred to be contemporaries of their ascetics, but the destiny of the saints is to remain timeless. Perhaps in this religious-historical choice lies the reason for the "cultural and technological backwardness of Russia," which foreign well-wishers are so eager to exaggerate? Or are the Bolsheviks again "guilty of breaking the bond of time"? - that seemed to the post-Soviet "historians" brought up in perestroika greenhouses on imported fertilizers and humus of anti-Stalinism. We believe that such statements about backwardness are still the same populist fashion tribute to superficial comparisons. But let us try to take as a basis not abstract, speculative, but ideological coordinates. With this approach, Soviet people (contemporaries of the eternally living Lenin) are as faithful as their ancestors, contemporaries of St. Seraphim of Sarov.

In Russia, they tend to adorn abstract philosophical constructions [3] that meet the ideological, and more precisely, the aesthetic tastes of ideologists. Moreover, this is not a kind of philosophy utilization, but its superation - ennoblement with the light of a moral ideal. If you believe Lenin, you will also believe in Bolshevism. Religion and faith in Russia are not identical: religion can be studied, faith must be professed, it is no accident that the idiom "Orthodox profession" has taken root in the Russian language. Although there are "religion" and "confession", they are hardly applied to Orthodoxy - probably because of their terminological character (and, therefore, their limitedness). On the other hand, the "Muslim profession" or, let us say, the Buddhist one does not fit well into the mind and hearing.

Religious images are in everyone's heart, but profession is always common and its purpose is to transform (and not just cement) people into nation. In this aspect, the Orthodox faith and the communist faith are more than similar. There were always people ready to gossip about the ecclesiastical nature of the communism builder Moral Code 
commandments. Belief in the symbolism of objects sanctified by the history that rested on them ("energies", in the version of St. G. Palamas) is another feature of the Russian mentality. Piety for relics was also brought up in the USSR: the pioneer commandment "when you tie a tie - take care of it, because it is the same color as a red banner." It was laughed at Judah's years of perestroika by stand-up buffoons: "when you buy a Snickers, you don't eat it, it is the same color as Mandela." However, the presence of mockingbirds only confirms both the fact of existence and the common character of faith (otherwise there is nothing to discuss and ridicule). D. Merezhkovsky considered "psychological religiosity" to be a Russian national trait [4].

To practice or to profess?

Your gaze, turned to yourself and around, Let it be partial and attentive, Let it be with you as a tried friend In the struggle, the truth is found.

O. Pisarzheuskaya

Russians are a people with a legendary history, for a legend is the surest way to overcome beautifully temporal predestination. However, it is one thing to admire the legend from afar, and it is quite another to exist in it and create it. The latter has always been both difficult and dangerous. Not to live in vain - it was meant to remain in good memory in Russia. Of course, to be legendary and become successful - these are different things and hardly compatible. Legendary thing is not famous at all (Pasternak's "it is ugly to be famous"), taking into consideration national Kenotism (kenosis), it is rather obscure. By the way, even the authorship of the amazing epitaph at the Tomb of the Unknown Soldier ("your name is unknown, your deed is immortal") is still debatable. Glamorous clothes of cult people and heroes of the mass cult are too close for Russian heroes, therefore prints with Lenin or Gagarin look vulgar, and T-shirts with the faces of Sergius of Radonezh or Zoya Kosmodemyanskaya are sacrilegious and completely unthinkable. On the contrary, this is quite common in the USA, like the replicated Che Guevara or Jesus Christ superstar. For Russians, ideological differences are found more in moral than in speculative orientations. Foreign ideologies are perceived as hostile, insulting national or religious feelings. The bourgeois paradigm proceeds from the existing order of things and is therefore immanently adaptive, even criticizing reality. Domestic ideology designated the image of the future rather than served the current needs of social life, much less the political regime (and here even communism and the theory of official nationality are somewhat related).

Could Svetlov's "a guy who despises convenience" accept the fact that in times of peace he would have to create these conveniences himself? Moreover, with the fact that there will be people who believe that the only meaning of life is the use of amenities. It seems that archpriest Avvakum, Pestel, Herzen, Pobedonostsev, Sventsitsky, and Lenin would have answered this question unambiguously (albeit differently). They waged a desperate ideological struggle with unconsciousness, a quagmire of domestic comfort, and a philistine call to "stop in time" in Russia. That is why John the Baptist will remain an eternal symbol in Russian culture - a selfless ascetic, that same "guy who despises convenience".

The wholeness of nature is in selfhood, in the courage to live with the principles that you profess. This was precisely what many Western philosophers lacked (Nietzsche is a bright example), while Russian thinkers tried to liven up the sermon by personal example. A 
good deed, a good feeling, purity in behavior are higher than all philosophy and everything else in the world, believes N. Strakhov [5]. According to Val. Muravyov, "where there was no thought in the European sense, perhaps there was more than thought - an integral sensation of reality" [6]. In our opinion, the specificity of Russian history is not in achievements and successes (who has not got them?), but in striving for such rare wholeness, thanks to which Russia, like the Phoenix, has repeatedly risen from the ashes. They even professed Marxism here (and not just "practiced"), it became a worldview for millions, and this is impossible without faith. Here is a fragment of the "official song" with the words of E. Dolmatovsky:

Communism is our holy faith

It is testing by construction sites and battle.

Only with the truth of a personal example

You can prove to people what we are worth!

The ideological formulas in Russia are frankly personal (recall the lines of Mayakovsky: "whose life example should I follow?"). Hence the leaderism, and the present day dissolute "Putinists", floundering in the extensible coordinates of fundamental lack of principles. As you can see, the key nuance is the scale of the leader's personality, therefore, within the framework of seemingly one idea, we have uncompromising and immortal MarxismLeninism at one pole, at the other - hypocrisy of Gorbachev's "socialism with a human face".

The desire to simplify and make ourselves simpler is the eternal temptation of mankind. It is founded on the same energy conservation, optimization of resources use, and adaptability. People who look at life simpler will inevitably lose control of themselves and morally fall, reducing their inherent creative potential to mechanistic observance of rituals. There is not a long way from formalism to obscurantism (always militant, by the way). That is why the felon (according to M. Ancharov) is a Philistine brought to the point of absurdity [7]. Having adapted and understood the most affordable way of adaptation, the Philistine does not want to develop. On the contrary, he is for the professing of the "life hack" axiom. Such adherents of simple external rules cannot live peacefully, because their survival does not depend on creativity and imagination, but on expanding the zone of practiced concepts exploitation. Consequently, the notorious "one-sided development" of the military, the narrow-mindedness of the ultra-patriots and Islamic fundamentalism are not so different. Perhaps the great number of those offended and insulted in their civic and religious feelings today is due to the lack of ideological immunity among the masses. Therefore, they adhere to the negative methods of legal regulation - prohibitions, restrictions and protection of the immunocompromised ones from potentially harmful influences. A kind of virus of ideological human immunodeficiency and attacks of patriarchal asthma.

From this point of view, the difference between extremism and the norm, and the totalitarian sect from the "traditional" religion is quite obvious. Is it not that all the evil tricks will ultimately remain tricks? Moreover, they sow madness and loop history. According to Vyach. Ivanov, the hypostases of Satan "manifest themselves in separation and mutual denial, look in different directions and contradict one another, but they cannot individually identify themselves and have to search for their essence and find it in horror - each in its opposite, repeating in itself the abyss of the other, as two empty mirrors pointing one upon the other" $[8]$.

Only those things that open the horizons of life instill faith. All sorts of promises of immediate selfish interest satisfaction and prompt fulfillment of purely tangible desires are 
from the evil one. This distinguishes the husband from the seducer, and the prophet from the demagogue. Anti-humanism is always cynical, and therefore utilitarian and technological, because it simplifies. Here is its usability, therefore - it is almost useful for solving everyday problems. Extremism is rightly called cultural suicide: in fact, it is the quintessence of philistinism as a way to take leave of culture and thereby simplify life. It turns out that the refutation of extremism by simple contesting the reliability of its "ideological" sources does not yet promise us victory. Leaders of totalitarian sects can turn out to be strong-minded (albeit not spiritual) people whose lifestyle (but not always a way of thinking) attracts many people who are tired of the lies and hypocrisy of officially propagandized values. In addition, if extremism is measured only by difference from common truths, it is easy to confuse the sectarian and troublemaker with the revolutionary, as they had once chosen between Barabbas and Christ. However, the value of Christianity is that it complicates life with the ideal of love, while the covenant of revenge is the application of the causality law. Extremism and sectarianism never complicate. On the contrary, they populistically reduce everything to a digestible semi-useful surrogate. The broadest possible understanding of extremism in a complex, ideological sense makes it possible to prevent an expansive interpretation of extremism in a legal context. Only this way will help us to detect signs that are not fundamentally regulated by law (psyche), but no less dangerous than those manifestations for which criminal liability is provided.

We live not so much in a world full of evil, but in the middle of the supermarket of decent and good ideas perversions. Evil is antagonistic to human nature, lies offer an attractive (and most importantly affordable) ersatz of good, that is what the hellish simulacra and euphemisms are terrible for. There is an ideology in the country, which means that you can focus on solving current problems and particular issues, improving the details of the state mechanism or increasing the level of public welfare. However, when there is no ideology (respectively, no meaning of life), how can you not think about the main and the eternal? Getting stuck on everyday details in such conditions is akin to perseveration and confabulation - pathologies of consciousness, symptoms of impending dementia. By analogy with the aphorism of Archimedes, the priority question in the matter of changing the world through the creation of history is the search for a fulcrum around which circumstances and attitudes are harmonized. Moreover, this fulcrum, in our opinion, is not in the plane of economics or politics, but in the multidimensional space of faith or rather ideology in relation to society.

The image is completed, like a magic circle drawn in the heart, but it is not sharp and clear in details as a rule. Therefore, torn apart for analysis, it loses its ability to inspire. Social system presupposes precisely the image, the holistic perception of construction, psychology and ethics. We certainly destroy harmony, pulling individual details out of context. But are we building a new one? Here is a vivid example: openly rude prejudice in highlighting socialism as a totalitarian machine, where screw-people are mercilessly tightened against the thread on purpose. The past has been defamed and ridiculed. But what has replaced it? Depressing perestroika? Liberal demagogy? Big lie? As A. Voznesensky wrote: "they removed the illumination, but did not light candles." Now, for example, political show strategists and cheering propagandists try on a padded jacket of the "Russian world" apostles (actually blockheads) with Russians, but the ordinary kind of education of an average Russian land inhabitant does not allow him to write the phrase "Russian world" without errors.

Everything casts a shadow and has a dark side in oblique light. There is science and its shadow - pseudoscience, there is the intelligentsia and a kind of intelligentsia. However, 
the shadows disappear at the zenith, at the point of the highest ascension of the star. So superation is similar to soaring above oneself, when the dark side (like any alternative) disappears, a person is transformed by creativity - and therefore becomes inimitable (for epigones are the same shadows of talent). American "well-wishers" liked to talk about alternatives to communism before the tragic collapse of the USSR, imposing a bipolar construction of the world. In the log run, propagandists have not succeed in this "maneuver in the sphere of consciousness" (V. Belinsky's phrase): the bipolar world is not viable, and the weighty argument, the "great-power" of Russian-Federussian is nothing more than the ugly shadow of the USA, comical and changeable, like all shadows.

\section{Irrationalism of historical responsibility}

And obsession is always right, when it finds its words. N. Dobronravou

The light of intellect (according to P. Novgorodtsev) "directs the path of history, but it does not eliminate its creative depth, its infinite possibilities, its irrational foundations" [9]. Self-determination, self-criticism, self-awareness are paradoxical things, they include separateness and inseparability of opposed concepts (this thesis has been brilliantly proved by E. Ilyenkov). To analyze the phenomenon of self-awareness is the same as dividing one by zero. In general, it is customary to name something in order to repeat the name (and, accordingly, the phenomenon) subsequently. Of course, such a repetition provokes the replication of the phenomenon itself: in this way, the sacrament degrades to charlatanism, to spells and formulas. This means that every uttered thought is a lie (for comparison: in the format of Thomas's famous theorem, "situations defined by people as real are real in their consequences", in a vulgar interpretation - "thought is material"). It turns out that the only one thinks correctly, who could be misunderstood, who implies more than explains. Moreover, the masses usually take the surface of words for the depth of meaning. That is why all genuine aphorisms are very ambiguous, but invariably convincing, ideological.

It is characteristic: a Russian person is inclined to "reason" in the particular, thinks rationally and quite scientifically, while in global issues he is extremely extravagant, "the heart believes in miracles." Talented people do not belong this world, and our people do not put up with ordinariness. That is why Russians absorb and develop progressive ideas from a wide variety of cultures so quickly. For the same reason, the archaic (at first glance) society is in constant expectation of desperate reforms and risky experiments. At the same time, the above-stated determines perhaps recklessly fanatical adherence to "advanced principles", which often take the most unexpected forms for the rationalist. It is interesting that none of the domestic Euro-transformations had a form that resembled a "civilian" prototype even remotely. This speaks, first of all, about the initial imperfection of the prototype, which is shamelessly exposed in the process of its profession. The paradox is that idealists were predominantly the reformers-practitioners in Russia, while pragmatists and skeptics preferred theoretical-critical reasoning. This underlined the national priority of moral over ethical, social over political, and political over economic. Ideology was most often created by cultural figures in Russia, and officials were engaged in culture. It is important to emphasize: a scientist, a teacher (as ideological personalities), and culture bearers in general, should not become victims of an ideological engagement (in the words 
of I. Reznik, "he, who has the flame inside, will never burns in fire"). Enlightenment is a collective affair of mankind, therefore - international, but not cosmopolitan.

Just as a person craving for spiritual food does not notice household inconveniences and even hunger, gnawing at the granite of science, so do Russian people: believing in a bright future, they did not make a cult of food and prosperity. Such creative burning is common to everyone, but not everyone is able to keep himself or herself in such a concentrated-stressed condition for a long time. Of course, it is much easier to set goals that are feasible in everyday life and to have a small bird in the hand, and here the result is more obvious. At the same time, no one canceled a crane in the sky, and the sky in general. (Russian proverb: "it is better to have a small bird in the hand than a crane in the sky"). The bourgeoisie is closer to the rational formula of social responsibility in the spirit of compensation. In particular, the Euro-approach to socialism is like the story of an exsupplier, whom (for the lack of fighting skills) partisans sent to the village occupied by the Nazis to distribute leaflets. He returned back with a bag of Deutschmarks - he managed to sell them with a profit. Quasi-socialism is pragmatic and intended for the material filling of consumer basket. It may be not a bad thing, but narrow and without perspective. Besides, it is a shame for the partisans...

Russia professed the irrationalism of historical responsibility. The deeds of many Russian princes and tsars, oriented towards progress, were unbearable for their subjects (verses by N. Glazkov: "the more interesting a century is for a historian, the sadder it is for a contemporary"). Nevertheless, the civilizational path of Russia (intuitively or consciously) had been planned correctly: both at christening and during the Horde yoke, in the Time of Troubles - the choice was always made according to the vector of complicating the archaic. The most radical one before the revolution (Peter's the Great) was in the direction of Europe, which did not simplify the picture of the world, in contrast to the halal-haram East.

Religion is always irreconcilable in its spirit, argued G. Chulkov [10]. In other words, Christian politics in the form of a technology of compromise is impossible, that is where the Russian rejection of political intrigues comes from. Let us compare: the civil war in Russia 1918-1920 is similar to the Thirty Years War in some ways, both are of a religious nature. But if in Europe the parties merely indicated their positions and finally came to the conclusion that the Truth common for all was absurd (Peace of Westphalia), then here won not the Reds but the Truth which they fought for and which they defended. The Whites fought with the Reds, and the Reds fought for justice and a better life, but not with the Whites at all. The protest is not capable of having anything constructive in itself. The victory of the Bolsheviks was determined by their faith, and not by brute force or sophisticated political program. We emphasize specifically: the Communists won, they did not outplayed - these concepts form a "huge distance" in moral terms.

Messiahship dictates strict conditions to politics: domestic diplomacy was based on moral principles until perestroika (the Holy Alliance against Napoleon, liberation of Slavic brothers from the Turks, proletarian internationalism, liberation of Europe from fascism). Undoubtedly, moral diplomacy is much more complicated than Talleyrand's cynical and unprincipled one. Our national tradition recognizes the positive features as belonging to people, the negative ones - to the individuals, who will be converted and corrected by their own people. They resolved in Russia the dilemma of the particular and the general (conciliar personality, collective image). The impeccability of the image cannot be tarnished by the vices of the people who make it up. This manifested Orthodox intolerance of sin and pity for sinners. Personal repentance of everyone excluded the repentance of the nation itself: the mathematical rule for the items sum is not applicable here, because everyone, sensing his 
belonging to the nation, tried not to disgrace his national honor. The Gorbachev's (in fact, Brzezinski's) formula of national repentance automatically recognized every Russian (even not yet born) as an accomplice in supposedly created historical evil, as long as the "evil empire" was identified with all Russian.

Ideology always appeals to moral strength. Power unites people into nation only by anti-idea, by struggle with something. The struggle for something is the sphere of ideological superation. Will and reason, "the theory of two swords" - this is the harmonization of ideological and power structures, which reached the peak in the USSR, where the party line blessed power and (when necessary) straightened shifts and distortions in the party line implemented by the state. Now, it is prescribed to blame in all shortcomings not the chief, but the representatives of the authorities; not the president, but the party of power, parliament and government, sort of whipping boys. As a result spineless foolishness, spontaneous tyranny.

Ideology as a professed philosophy is incomparably higher than any speculativepalliative abstraction. The Russians comprehended the Kantian imperative in their own way. Dostoevsky's phrase "the main thing - love others as yourself" was very peculiarly embodied in the activities of the leaders of the nation that were merciless to themselves: both in politics (Lenin, Stalin, Peter I), and in science and art (Acad. Pavlov, Lomonosov, Tolstoy and Dostoevsky). The Russian self-sacrifice is in the grinding of unfair reality by the harsh world, in the dissolution of personality. But it is a supersaturated solution that is fraught with instant crystallization: of ideas and people in their struggle for justice. Let us say more: the absence of guarantees was conceived as the only possible guarantee of progress. Euro-democracy is ensured mainly by law. In the USSR, they were guided by ideological principles ("we care about the young everywhere, we honor the old people everywhere"). Russians prefer to live under the grace than under the law, because holiness is closer to them than accounting honesty. Nevertheless, this is the key to moral improvement. To go forward out of the main track means to be higher than predetermination, certainty and assurance, and therefore - to be freer.

According to one of the most touching misanthropes in Russian history, P. Chaadaev, "we are one of those nations that are hardly a part of humanity, but exist only to give the world some important lesson" [11]. Therefore, domestic history is rather a parable. Is not this a gospel tradition? Is not it absurd to consider Christ's earthly life as a detective and investigate the circumstances of whether with direct or indirect intent God sacrificed the Son to save people? This history is so genuine and universal that it will never fit into the framework of historiography, although its individual moments will be reflected there.

It seems to us that the ideological core of the national way of thinking lies in the optionality and insecurity of enlightenment. The Russian considers it indecent and blasphemous to torture God with claims "What will I have for all of this?" The point is not whether we will gain the Kingdom of Heaven by means of planned worship, but that both fasting and replete with food people a priori will not get any guarantees. Believers do not bargain with heaven, "for God has made everyone disobedient in order to have mercy on everyone" (Romans 11,32). Hence it follows that neither ceremonies, nor fasting, nor the repetition of prayers bring a person closer to God, but a righteous (it means creative) life, a sincere desire to be above one's imperfect nature. This is maximalism, it is naive and paradoxical! There soaring to the heights of the Spirit is possible where sinful excesses are inevitable.

As V. Odoevsky wittily remarked, history lays stone upon stone, not knowing what building it will erect [12]. Apparently, that is why the past was repeatedly re-turned in 
Russia: a rare ethical and aesthetic feeling, special historical perfectionism. Such is Russian trialectics: government loses its way in broad daylight (among three pine trees in Russian) and cuts them so that chips fly everywhere; philosophy sees a forest of problems behind the trees, and ideology requires a beautiful city to be built from this timber with a temple in the middle of it.

\section{References}

1. Pavel D. Simashenkov. About Russian version of historical progress // Modern European Researches. - Salzburg, 2019 .- No. 2. - P. 52-58

2. Fedotov G.P. Fate and Sins of Russia: Elect. Arts. on philosophy of Rus. History and Culture: In 2 vols. St. Petersburg, 1991-92.

3. Pavel D. Simashenkov. Aesthetics of History: the example of Russia // Modern European Researches. - Salzburg, 2019 .- No. 3. - P. 47-55

4. Merezhkovsky D.S. Collected works in 4 vol. V. 4. M .: Pravda.

5. A.A. Fet and his literary environment: in 2 vol. Correspondence with N.N. Strakhov. M., 2011.- Vol. 2.- S. 233-550

6. Muravyov V.N. Works. Book 1 M.: IMLI RAS, 2011, 704p.

7. Ancharov M.L. Works. M .: Lokid, 2001.496 p.

8. Ivanov V.I. Faces and masks of Russia. M., 1995. 671 p.

9. Novgorodtsev P.I. Works. M., 1995.543 s.

10. Chulkov G.I. About Mystical Anarchism / With the entry by Vyacheslav Ivanov on rejection of the world. St. Petersburg: Fakely, 1906. $79 \mathrm{p}$.

11. Chaadaev P.Ya. Philosophical letters. M .: Eksmo. 2006.763p.

12. Odoevsky V. F. Selected pedagogical works. M.: Uchpedgiz, 1955. 342 p. 


\title{
Симашенков Павел Дмитриевич,
}

кандидат исторических наук, доцент кафедры государственного и муниципального управления и правового обеспечения государственной службы

АНО ВО Университет "МИР", г. Самара

pavel.simashenckov@yandex.ru

\section{ИДЕОЛОГИЧЕСКОЕ ПРЕВОСХОЖДЕНИЕ ФИЛОСОФИИ}

\begin{abstract}
Аннотация. Статья посвящена исследованию соотношения идеологического $u$ философского компонентов в формировании мировоззрения. По мнению автора, для понимания отечественной истории и культуры принципиально важно взять за основу не спекулятивные, а идеологические координаты. Идеология как исповедуемая философия несравненно выше любой паллиативной абстракции. Необходимо не опускать культуру до уровня масс, но возвышать человека до уровня культуры, без культа невозможной.
\end{abstract}

Ключевые слова: русская философия, идеология, эстетика, религия, экстремизм, социальная этика, история, русская культура

\section{Введение}

Где остановилась философия вследствие ограниченности человеческих сил, там начинается проповедь. Л. Шестов

Системность - достоинство теории. Практика обыкновенно хаотична и ситуативна. С высоты прожитых лет допустимо сказать: в молодости не зазорно следовать какой-то доктрине, проверяя, сознательно осваивая ее на практике - так мировоззрение становится убеждением. Зрелое суммирование эмпирики, возможно, выше философии, поскольку выстрадано собственной жизнью. Идеологией, в юности внешне воспринимаемой (дело чести), всё начинается. Идеологией, ставшей внутренним убеждением (дело совести) и оттого убеждающей - завершается. По нашему мнению, значение практики в большей степени - негативного свойства: жизненный опыт защищает от догматизации и резонерства, т.н. "религии науки". Теория в идеологическом синтезе играет положительную роль; ретроспективное обобщение - лучшее средство расшифровать приметы и проложить дальнейший путь[1].

Философия - это усилия лучших умов сшить лоскуты бытия белыми нитками своего сознания. Внешний хаос упорядочивается внутренним миром. Весьма возможно, что христианские философы вышивают по канве бытия крестиком: по словам Г. Федотова, без внутреннего приобщения христианству невозможно никакое истолкование русской национальной идеи [2]. Своеобразное отношение к философии - также в полном соответствии с национальным талантом осваивать, не присваивая. Можно сказать, русским свойственно не столько сравнивать вечные вопросы в постановках разных мыслителей, сколько изучать возможные ответы, примеряя философские аксессуары к сермяжным ризам правды. "Самая бесполезная вещь на свете - быть правым", в этом тютчевском афоризме не просто горькая ирония непонятого человека, но еще и предупреждение: грех пользовать правду, низводя ее 
до кривды. Идея выхолащивается, переходя из воображения в соображение. И коченеет, переходя из сердца в цитатники.

\section{Идеология и вера}

Идеология, которой мы жили, имеет постоянный остов платонизма: видит не то, что видит, и имеет в виду не то, что имеет в виду но только памятью и живет.

В. Бибихин.

Любая мысль, буде ценна и будучи извлечена из контекста, формирует собственный контекст: пресуществляясь в искусстве, рождает шедевры; оплодотворяя политику - становится тенденциозной, делает культуру пародийной. Бывают периоды, когда культура и политика попеременно играют роли должного и сущего, но чаще соотносятся как реальность и действительность. В обеих есть ретро и прогрессивный компоненты, которые могут соприкасаться, быть параллельными или противоречить друг другу. Вряд ли можно утверждать, что ход вещей определяет культуру, и наоборот. Необходимо не опускать культуру до уровня масс, но возвышать человека до уровня культуры (без культа невозможной). Существенное и насущное претворяются в сознании, образуя тот континуум, коего современником человек себя признаёт.

Эра гениев никогда не наступит: они принадлежат Вечности, их крест одиночество и обреченность до поры пребывать в бренном мире, будучи не от мира сего. Они - носители и проводники непреходящих идеалов, оттого и живут, не ожесточаясь злобой дня. Русский народ издавна предпочитал быть современником своих подвижников, однако удел святых пребывать вне времени. Может быть, в этом религиозно-историческом выборе кроется причина "культурно-технологического отставания России”, которое так любят муссировать зарубежные доброжелатели? Или снова виновны большевики, “порвавшие связь времен”? - как оно привиделось постсоветским “историкам", взращенным в перестроечных парниках на импортных удобрениях и перегное антисталинизма. Нам представляется, подобные заявления об отставании - всё та же популистская дань моде на поверхностные сравнения. Но попробуем взять за основу не отвлеченные, а мировоззренческие, не спекулятивные, а идеологические координаты. При таком подходе советские люди (современники вечно живого Ильича) столь же верующие, как и их предки, современники Серафима Саровского.

В России склонны эстетизировать абстрактно-философические построения [3], отвечающие запросам идеологическим, а точнее - эстетическим вкусам идеологов. И это не утилизация философии, а ее суперация - облагораживание светом нравственного идеала. Если верите Ленину, уверуете и в большевизм. Религия и вера на Руси не тождественны: религию можно изучать, веру надлежит исповедовать, неспроста в русском языке прижилась идиома "православное вероисповедание". И хотя существуют "религия" и “конфессия", к православию они мало подходят наверно, в силу своей терминологичности (а, стало быть, ограниченности). С другой стороны, плохо ложится на ум и слух "мусульманское вероисповедание" или, скажем, буддийское.

Религиозные образы - в сердце каждого, исповедание же всегда общее и призвано претворять (а не просто цементировать) людей в народ. В этом аспекте вера православная и вера коммунистическая более чем схожи. Всегда были ёрники, 
готовые позубоскалить о церковности заповедей Морального кодекса строителя коммунизма. Вера в символизм предметов, освященных почившей на них историей ( “энергиями”, в варианте св. Г. Паламы) - еще одна особенность русского менталитета. Пиетет к реликвиям воспитывался и в СССР: пионерская заповедь "как повяжешь галстук - береги его, он ведь с красным знаменем цвета одного”. И высмеивался в иудину годину перестройки КВН-фиглярами: "а как купишь сникерс, ты не ешь его, он с самим Манделою цвета одного". Однако наличие пересмешников только подтверждает и сам факт существования, и общность веры (иначе нечего обсуждать и высмеивать). Д. Мережковский считал "психологическую религиозность" русской национальной чертой [4].

\section{Практиковать или исповедовать?}

Твой взгляд, обращенный в себя и вокруг,
Пусть будет пристрастным и пристальным,
Пусть будет с тобой как испытанный друг
В борьбе обретенная истина. О. Писаржевская

Русские - народ с легендарной историей, ибо легенда - самый верный способ красиво превзойти временнУю предопределенность. Но одно дело издалека восхищаться легендой, и совсем другое в ней существовать и ее сотворять. Последнее всегда было и трудно и опасно. Жить не зря - на Руси значило остаться в доброй памяти. Разумеется, быть легендарным и стать успешным - вещи разные и едва ли совместимые. Легендарность это отнюдь не известность (пастернаковское "быть знаменитым некрасиво"), с учетом национального кенотизма - скорее уж безвестность. Между прочим, даже авторство потрясающей эпитафии на Могиле Неизвестного Солдата ("имя твое неизвестно, подвиг твой бессмертен") до сих пор спорно. Русским героям тесны гламурные одёжки культовых персон и героев масскульта, потому принты с Лениным или Гагариным смотрятся пошловато, а маечки с ликами Сергия Радонежского или Зои Космодемьянской кощунственны и совершенно немыслимы. Напротив, в США подобное совершенно обычно, как растиражированный Че Гевара или Jesus Christ superstar. Для русских мировоззренческие разногласия обнаруживаются более в нравственных, нежели в умозрительных ориентирах. Ино-идеологии воспринимаются враждебными, оскорбляют национальные или религиозные чувства. Буржуазная парадигма по преимуществу отталкивается от существующего порядка вещей и потому имманентно адаптивна, даже критикуя действительность. Отечественная идеология скорее обозначала образ будущего, нежели обслуживала текущие нужды социального быта, тем паче - политического режима (и здесь в чем-то родственны даже коммунизм и теория официальной народности).

Мог ли светловский “парень, презирающий удобства" смириться с мыслью о том, что в мирное время эти удобства ему пришлось бы мастерить? А особенно - с тем, что появятся люди, полагающие смыслом жизни единственно пользование удобствами? Думается, на сей вопрос однозначно (пусть и неодинаково) ответили бы и протопоп Аввакум, и Пестель, и Герцен, и Победоносцев, и Свенцицкий, и Ленин. Непримиримая идеологическая борьба велась в России с бессознательностью, трясиной бытового комфорта, с мещанским призывом “вовремя остановиться". Оттого 
в русской культуре вечным символом останется Иоанн Креститель самоотверженный подвижник, тот самый “парень, презирающий удобства".

Цельность натуры - в самости, мужестве жить по тем принципам, какие исповедуешь. Именно этого недоставало многим западным философам (красноречивый пример - Ницше), в то время как отечественные мыслители старались животворить проповедь личным примером. Хороший поступок, хорошее чувство, чистота в поведении - выше всякой философии и всего другого на свете, считает Н. Страхов [5]. С точки зрения Вал. Муравьева, “там, где не было мысли в европейском смысле, было, быть может, больше, чем мысль - цельное ощущение действительности" [6]. По нашему убеждению, специфика отечественной истории не в достижениях и успехах (где их нет?), а в стремлении к такой вот редчайшей цельности, благодаря которой Россия, подобно Фениксу, многократно восставала из пепла. Даже марксизм здесь исповедовали (а не просто "практиковали"), для миллионов он стал мировоззрением, а без веры сие невозможно. Вот фрагмент "официальной песни" на стихи Е. Долматовского:

\author{
Коммунизм - святая наша вера, \\ Испытанье стройками и боем. \\ Только правдой личного примера \\ Можно людям доказать, чего мы стоим!
}

Идеологические формулы в России откровенно личностны (припомним строки Маяковского: “делать бы жизнь с кого?"). Отсюда вождизм, но оттуда же и нынешние беспутные “запутинцы”, бархтающиеся в растяжимых координатах принципиальной беспринципности. Как видим, ключевой нюанс - в масштабе личности вождя, поэтому в пределах одной, казалось бы, идеи, мы имеем на одном полюсе бескомпромиссный и бессмертный марксизм-ленинизм, на другом - фарисейство горбачёвского "социализма с человеческим лицом".

Стремление упрощать и опрощаться - вечное искушение человечества. В основе его всё то же сохранение энергии, оптимизация ресурсопользования, приспособленчество. Люди, глядящие на жизнь проще, неизбежно распускаются и морально опускаются, низводя заложенный в них творческий потенциал до механистического следования обрядам. От формализма недалеко и до обскурантизма (всегда, кстати, воинствующего). Вот почему уголовник (по версии М. Анчарова) есть мещанин, доведенный до абсурда [7]. Приспособившись и уяснив самый доступный способ адаптации, обыватель не желает развиваться. Наоборот, он - за исповедание заныканной им аксиомы “лайфхака". Такие адепты простых внешних правил не могут жить мирно, ибо выживание их зависит не от творчества и фантазии, а от расширения зоны эксплуатации практикуемых понятий. Следовательно, пресловутая "односторонняя развитость" военных, узколобость ура-патриотов и исламский фундаментализм не столь различны меж собой. Возможно, нынешнее обилие обиженных и оскорбленных в своих гражданственных и религиозных чувствах обусловлено отсутствием у масс идеологического иммунитета. Потому и придерживаются негативного метода правового регулирования - запретов, ограничений и ограждения иммуно-ослабленных от потенциально вредных влияний. Своего рода вирус идеологического иммунодефицита человека и приступы патриархальной астмы. 
С этой точки зрения вполне очевидно отличие экстремизма от нормы, а тоталитарной секты - от “традиционной” религии. Не в том ли, что все дьявольские уловки уловками в конечном счете и останутся? Более того, они сеют безумие и зацикливают историю: словами Вяч. Иванова, ипостаси сатаны "являют себя в разделении и взаимоотрицании, глядят в разные стороны и противоречат одно другому, а самобытно определиться порознь не могут и принуждены искать своей сущности и с ужасом находить ее - каждое в своем противоположном, повторяя в себе бездну другого, как два наведенных одно на другое пустых зеркала" [8].

Веру вселяет лишь то, что открывает горизонты жизни. Всякие обещания сиюминутного удовлетворения шкурного интереса и оперативного исполнения чистоконкретных желаний - от лукавого. Этим муж отличен от соблазнителя, а пророк - от демагога. Антигуманизм всегда циничен, а потому утилитарен и технологичен, ибо упрощает. Здесь и юзабельность, возможность им пользоваться, стало быть - почти полезность для решения житейских проблем. Экстремизм справедливо называют культурным суицидом: по сути, это квинтэссенция мещанства как способа опростаться от культуры и тем самым опростить жизнь. Выходит, опровержение экстремизма одним лишь оспариванием достоверности его "идейных" источников - еще не сулит победы. Лидеры тоталитарных сект могут оказаться сильными духом (хотя и не духовными) людьми, чей образ жизни (но не всегда образ мыслей) привлекает множество людей, уставших от лжи и лицемерия официально распропагандированных ценностей. И если мерить экстремизм только отличием от прописных истин, легко спутать сектанта и смутьяна с революционером, как когда-то выбирали между Вараввой и Христом. Однако ценность христианства в том, что оно осложняет жизнь идеалом любви, в то время как завет мести есть применение закона причинности. Экстремизм и сектантство никогда не усложняют. Наоборот, популистски опускают до удобоваримого условно-пользительного суррогата. Предотвратить расширительное толкование экстремизма в юридическом контексте способно максимально широкое его осознание в смысле комплексном, идеологическом. Только так обнаружатся признаки, принципиально не регулируемые правом (психика), но не менее опасные, чем те проявления, за которые предусмотрена уголовная ответственность.

Мы живем не столько в мире, преисполненном зла, сколько посреди супермаркета извращений добрых и хороших идей. Зло противно людской природе, ложь предлагает привлекательный (а главное - доступный) эрзац добра, вот чем страшны адские симулякры и эвфемизмы. Есть в стране идеология - значит, можно сосредоточиться на решении текущих проблем и частных вопросов, совершенствуя детали государственного механизма или повышая уровень народного благосостояния. Но когда идеологии нет (соответственно, смысла жизни - тоже), как можно не задумываться о главном и вечном? Застревание на будничных деталях в таких условиях сродни персеверациям и конфабуляциям - патологиям сознания, симптомам грядущего слабоумия. По аналогии с афоризмом Архимеда, в деле изменения мира сотворением истории, первоочередной вопрос - поиск точки опоры , вокруг которой гармонизируются обстоятельства и отношение к ним. И опора сия, по нашему убеждению - не в плоскости экономики или политики, а в многомерном пространстве веры. Применительно к социуму, еще вернее - в сфере идеологии.

Образ завершен, как начертанный в сердце магический круг, но, как правило, нерезок и неясен в деталях. А потому, разъятый на части для анализа, теряет способность вдохновлять. Общественный строй предполагает именно образ, 
целостное восприятие устройства, психологии и этики. Выхватывая отдельные детали из контекста, мы непременно разрушаем гармонию, но выстраиваем ли новую? Яркий пример: неприкрыто-хамовитая предвзятость в освещении социализма как тоталитарной машины, где людям-винтикам безжалостно “закручивают гайки”, причем принципиально - против резьбы. Прошлое ошельмовано и осмеяно, а что пришло на смену - перестроечная чернуха? Либеральная демагогия? Скрепная ложь? Как у А. Вознесенского: “сняли иллюминацию, но не зажгли свечей”. Сейчас, к примеру, шоу-политтехнологи и ура-пропагандисты примеряют на россиян ватник апостолов (а получается - остолопов) "русского мира", но средненькое образованьишко усреднённого россиянца не позволяет тому даже написать слово "русский мир" без ошибок.

В косопадающем свете всё отбрасывает тень и имеет темную сторону. Есть наука и ее тень - наукообразие, есть интеллигенция и интеллигентщина. Но в зените, в точке высшего подъема светила, тени исчезают. Так и суперация подобна воспарению над собой, когда темная сторона (как всякая альтернатива) пропадает, человек преображается творчеством - и оттого становится неподражаемым (ибо эпигоны - те же тени таланта). До трагического развала СССР американские "доброжелатели" любили рассуждать об альтернативах коммунизму, навязывая миру биполярное устройство. По большому счету, и сей “маневр в сфере сознания" (фраза В. Белинского) пропагандистам не удался: нежизнеспособен двуполярный мир, и весомейший аргумент, великодержавная Рашн-Федарашн - не более чем уродливая тень США, комичная и изменчивая, как все тени.

\section{Иррационализм исторической ответственности}

И одержимость всегда права, когда находит свои слова. Н. Добронравов

Свет разума (по мнению П. Новгородцева) "направляет пути истории, но не устраняет ее творческой глубины, ее бесконечных возможностей, ее иррациональных основ" [9]. Самоопределение, самокритика, самосознание суть вещи парадоксальные, они заключают в себе неслиянность и нераздельность противопоставляемых понятий (данный тезис блестяще доказан Э. Ильенковым). Проанализировать феномен самосознания - то же, что единицу поделить на ноль. Вообще что-либо принято называть, дабы повторить название (и, соответственно, явление) впоследствии. Разумеется, подобное повторение провоцирует и тиражирование самого явления: так таинство деградирует до шарлатанства, до заклинаний и формул. Значит, всякая изреченная мысль есть ложь (для сравнения: в формате знаменитой теоремы Томаса “ситуации, определенные людьми как реальные, реальны по своим последствиям”, в вульгарной трактовке - "мысль материальна"). Выходит, правильно мыслит лишь тот, кого могут понять неправильно, кто больше подразумевает, чем излагает. А массы поверхностную гладь словес обыкновенно принимают за глубину смысла. Оттого-то все подлинные афоризмы весьма неоднозначны, но неизменно убедительны, идеологичны.

Характерно: в частностях русский человек склонен “соображать", мыслит рационально и вполне научно, тогда как в вопросах глобальных - на редкость нерасчетлив, “сердце верит в чудеса”. Талантливые люди не от мира сего, а наш народ 
не мирится с обыденностью. Вот отчего русские столь быстро впитывают и развивают прогрессивные идеи самых разных культур. По той же причине архаичный (на первый взгляд) социум пребывает в перманентном ожидании отчаянных преобразований и рискованных экспериментов. Вместе с тем, вышеназванное определяет и возможно безоглядно-фанатичное следование “передовым принципам", которые зачастую принимают самые неожиданные для рационалиста формы. Занятно, что ни одно из отечественных евро-преобразований не имело вида, хотя бы отдаленно напоминающего "цивильный" прототип. Это говорит, в первую очередь, об изначальном несовершенстве прототипа, которое бесстыдно обнажается в процессе его исповедания. Парадокс в том, что преобразователями-практиками в России были преимущественно идеалисты, в то время как прагматики и скептики предпочитали теоретико-критические умствования. В этом сказался национальный приоритет нравственного над моральным, социального над политическим, а политического над экономическим. В России идеологию создавали чаще всего деятели культуры, а культурой занимались чиновники. Важно подчеркнуть: ученый, преподаватель (как личности идейные), да и вообще носители культуры не должны становиться жертвами идеологического ангажемента (словами И. Резника, "в ком огонь пылает, тот вовек не горит в огне”). Просвещение есть соборное дело человечества, следовательно интернациональное, но не космополитическое.

Как человек, жаждущий пищи духовной, не замечает бытовых неудобств и даже голода, разгрызая гранит науки, так и русские люди: веруя в светлое будущее, не делали культа из еды и житейского преуспеяния. Подобное творческое горение свойственно всем, но не каждому дано долго поддерживать себя в столь сосредоточенно-напряженном состоянии. Разумеется, куда проще ставить себе посильно-бытовые цели и лапать ручных синиц, тут и результат очевиднее. В то же время никто не отменял журавля в небе, как и небо вообще. Буржуазии ближе рациональная формула социальной ответственности в духе компенсации. В частности, евро-подход к социализму напоминает историю экс-снабженца, которого (за неимением боевых навыков) партизаны отправили в оккупированную фашистами деревню распространять листовки. Он вернулся в отряд с мешком дойчмарок выгодно распространил, стало быть. Квази-социализм прагматичен и заточен под материальное насыщение потребкорзины. Оно, возможно, и неплохо, но узко и лишено перспективы. А, кроме того, перед партизанами неудобно...

Россия исповедовала иррационализм ответственности исторической. Деяния многих русских князей и царей, ориентированные на прогресс, были невыносимы для их подданных (стихи Н. Глазкова: “чем столетье интересней для историка, тем для современника печальней”). И все же цивилизационный путь России (интуитивно, осознанно ли) намечен верно: и при крещении, и в период ордынского ига, и в Смутное время - выбор всегда осуществлялся по вектору усложнения архаики. Самый радикальный перед революцией (петровский) был в сторону Европы, не упрощавшей картину мира, в отличие от халяль-харамного Востока.

Религия по духу своему всегда непримирима, утверждал Г. Чулков [10]. Иными словами, христианская политика в виде технологии компромиссов - невозможна, вот откуда русское неприятие политиканства. Сравним: гражданская война в России 1918-1920 гг. в чем-то похожа на войну Тридцатилетнюю, обе - религиозного характера. Но если в Европе стороны всего лишь обозначили свои позиции и в итоге пришли к выводу об абсурдности единой для всех Истины (Вестфальский мир), то у нас победили не красные, а Истина, на стороне которой те воевали и которую 
отстаивали. Белые воевали с красными, а красные - за справедливость и лучшую жизнь, но в принципе - вовсе не с белыми. Протест не способен иметь в себе ничего конструктивного. Победа большевиков определилась их верой, а не грубой силой или изощренностью политической программы. Подчеркнем особо: коммунисты именно победили, а не выиграли или переиграли - в моральном плане эти понятия образуют “дистанцию огромного размера".

Мессианизм диктует политике жесткие условия: до самой перестройки отечественная дипломатия базировалась на нравственных началах (Священный союз против Наполеона, помощь в освобождении братьев-славян от турок, пролетарский интернационализм, освобождение Европы от фашизма). Бесспорно, моральная дипломатия куда сложнее циничной и беспринципно-“талейрантной”. Наша национальная традиция положительные черты признаёт за народом, отрицательные за отдельными лицами, коих свой же народ перелицует и исправит. Так на Руси разрешалась дилемма отдельного и общего (соборная личность, собирательный образ). Безупречность образа не запятнать пороками людей, его составляющих. В этом проявлялась православная нетерпимость к греху и жалость к грешникам. Личное покаяние каждого исключало покаянность собственно нации: тут неприменимо правило о сумме слагаемых, ведь каждый, ощущая принадлежность к народу, старался не опозорить чести ни своей, ни национальной. Горбачёвская (а по факту бжезинская) формула национального покаяния автоматически признавала каждого русского (даже еще не родившегося) соучастником якобы сотворенного исторического зла, коль скоро “империя зла" отождествлялась со всем русским.

Идеология всегда апеллирует к нравственной силе. Власть объединяет людей в народ только анти-идеей, борьбой с чем-то. Борьба за что-то - сфера идеологической суперации. Воля и разум, “теория двух мечей" - это и есть гармонизация идеологических и властных структур, достигшая вершины в СССР, где линия партии благословляла власть и (когда нужно) спрямляла сдвиги и перекосы в реализуемой государством партийной линии. Ныне же во всех недочетах предписано винить не предстоятеля, а представителей власти; не президента, а партию власти, парламент и правительство, эдаких мальчиков для битья. В итоге - безвольная неразумность, стихийная тирания.

Идеология как исповедуемая философия - несравненно выше любой спекулятивно-паллиативной абстракции. Русские по-своему осмыслили кантовский императив. Фраза Достоевского “главное - люби других, как себя" весьма своеобычно воплощалась в деятельности беспощадных к себе лидеров нации: как в политике (Ленин, Сталин, Петр I), так и в науке и искусстве (акад. Павлов, Ломоносов, Толстой и тот же Достоевский). Русская жертвенность самозаклания - в перемалывании суровым миром несправедливой действительности, в растворении личности. Но именно пересыщенный раствор чреват мгновенной кристаллизацией: и идей, и людей в их борьбе за справедливость. Скажем больше: отсутствие гарантий мыслилось единственно возможной гарантией прогресса. Евро-демократия обеспечивается преимущественно правом, в СССР руководствовались идеологическими установками ("молодым везде у нас дорога, старикам везде у нас почет"). Русские предпочитают жить под благодатью, нежели под законом, потому святость им ближе, чем бухгалтерская честность. Но в этом и залог нравственного совершенствования. Идти вперед не по колее означает быть выше заданности, определенности и гарантированности, а потому - свободнее. 
По мнению одного из самых трогательных мизантропов в русской истории, П.Чаадаева, "мы принадлежим к числу тех наций, которые как бы не входят в состав человечества, а существуют лишь для того, чтобы дать миру какой-нибудь важный урок" [11]. Стало быть, отечественная история - скорее притча. Но не таково ли предание евангельское? Не дико ли считать детективом земную жизнь Христа и расследовать обстоятельства того, с прямым или косвенным умыслом Бог жертвовал Сыном во спасение людей? История сия настолько подлинная и всеобщая, что никогда не впишется в рамки историографии, хотя отдельные ее моменты и будут там отражены.

Нам представляется, идеологическая сердцевина национального образа мыслей в необязательности и необеспеченности просветления. Русский человек считает неприличным и кощунственным пытать Бога претензиями "а что мне за всё это будет?" Дело не в том, обретем ли мы Царствие Небесное путем планового говения, а в том, что и постящиеся и сытые априори не взыскуют каких-либо гарантий. Верующие не торгуются с небесами, "ибо всех заключил Бог в непослушание, дабы всех помиловать" (Рим. 11, 32). Из сказанного следует, что ни обряды, ни пост, ни повторение молитв не приближают человека к Богу, а приближает праведная (значит - творческая) жизнь, само искреннее стремление быть выше своей несовершенной природы. Это максимализм, он наивен и - парадоксален! Где неизбежны греховные эксцессы, допустимо и воспарение к вершинам Духа.

Как остроумно заметил В. Одоевский, история накладывает камень на камень, не зная, какое возведет здание [12]. Видимо, поэтому в России многократно перелицовывали прошлое: редкое этико-эстетическое чувство, особенный исторический перфекционизм. Такова русская триалектика: власть путается в трех соснах и рубит их так, что летят щепки; философия видит за деревьями лес проблем, а идеология предписывает из этого леса выстроить красивый город, и посреди него возвести храм.

\section{Ссылки на источники}

1. Pavel D. Simashenkov. About Russian version of historical progress // Modern European Researches. - Salzburg, 2019. - №2. - P. 52-58

2. Федотов Г.П. Судьба и грехи России: Избр. ст. по философии рус. истории и культуры: В 2 т. СПб., 1991-92.

3. Pavel D. Simashenkov. Aesthetics of History: the example of Russia // Modern European Researches. - Salzburg, 2019. - №3. - P. 47-55

4. Мережковский Д.С. Собр.соч. В 4 т. Т.4. М.: Правда.

5. А.А. Фет и его литературное окружение: в 2 кн. Переписка с Н.Н. Страховым. М., 2011. Кн.2.- C. 233-550

6. Муравьев В.Н. Сочинения. Кн. 1 М. : ИМЛИ РАН, 2011, 704с

7. Анчаров М.Л. Сочинения. М.: Локид, 2001. 496с.

8. Иванов В.И. Лики и личины России. М., 1995. 671с.

9. Новгородцев П.И. Сочинения. М., 1995. 543с.

10. Чулков Г.И. О мистическом анархизме / Со вступ. статьей Вячеслава Иванова о неприятии мира. Спб.: Факелы, 1906. 79 с.

11. Чаадаев П.Я. Философические письма. М.: Эксмо. 2006. 763с.

12. Одоевский В. Ф. Избранные педагогические сочинения М.: Учпедгиз, 1955. 342с. 